\title{
Integrated modelling tools to support risk-based decision-making in marine spatial management
}

\author{
V. Stelzenmüller*, T. Schulze, H. O. Fock, J. Berkenhagen \\ Johann Heinrich von Thünen Institute (vTI), Federal Research Institute for Rural Areas, Forestry and Fisheries, \\ Institute of Sea Fisheries, Palmaille 9, 22767 Hamburg, Germany
}

\begin{abstract}
The implementation of an ecosystem approach to marine spatial management requires practical tools to support risk-based decision-making. We combined a Bayesian Belief Network with a Geographical Information System (GIS) for the spatially explicit quantification of the ecological and economic risks of spatial management options. As an example we assessed the German exclusive economic zone (EEZ) in the North Sea to determine the potential effects of 2 scenarios on the vulnerability of plaice Pleuronectes platessa to fishing, fishing fleets and their revenues. In the first scenario we simulated a shift in plaice distribution due to changes in bottom temperatures to assess spatial management options. Then we imitated an expansion of offshore wind energy development with an associated reallocation of international fishing effort to assess the ecological and economic consequences. We predicted that an increase of $0.5^{\circ} \mathrm{C}$ in the average bottom temperature would require a significant reduction in fishing effort to maintain the current relative level of the vulnerability of plaice to fishing. The likely consequences of the second scenario were a homogenous increase in plaice catches around the areas closed for fishing, together with a decrease in the vulnerability of plaice to fishing within $17 \%$ of the study area. Our results showed the great potential of this framework to integrate the spatially explicit assessment of the economic and ecological risks of spatial management options. We conclude that this modelling framework can support the implementation of an ecosystem approach to marine spatial management, as it enables the derivation of probabilistic estimates which can be used directly in riskbased decision-making.
\end{abstract}

KEY WORDS: Bayesian Belief Network - Fishing effort - GIS - Plaice - Pleuronectes platessa • Offshore wind energy $\cdot$ Regression kriging

\section{INTRODUCTION}

Worldwide, the intensity and frequency of marine uses is increasing, together with their demand for sea space, which results in growing human pressures on coastal and marine ecosystems (Halpern et al. 2008). Thus, there is an urgent need for integrated and ecosystem-based management approaches that enable a sustainable development of marine resources while safeguarding marine environmental health (Leslie \& McLeod 2007, Ruckelshaus et al. 2008). Place-based or spatial management such as marine spatial planning (MSP) is seen to facilitate an ecosystem-based management (Lackey 1998). MSP is an integrated planning framework that informs management about the spatial distribution of activities in the ocean in order to support current and future uses of ocean ecosystems and maintain the delivery of valuable ecosystem services for future generations in a way that meets ecological, economic and social objectives (Foley et al. 2010). National and international policies and directives such as the EC Marine Strategy Framework Directive (MSFD; Commission E 2008) recognise this need to address human pres- 
sures in the marine environment and promote an ecosystem approach to management by using tools such as MSP. For instance, the national implementation of the MSFD comprises an assessment of human pressures and their impacts on the marine environment, together with the specification of programs of measures, such as management and mitigation measures or monitoring programs. Thus, future management measures are inevitably linked to the spatial management of human uses as it is defined in national marine plans. Spatial management tools such as MSP and ocean zoning are being developed and implemented worldwide (Douvere \& Ehler 2009). Based on growing international experience, practical guidelines for spatial planning already exist (COM 2008, Ehler \& Douvere 2009). However, these general guidelines do not provide the scientific means to evaluate the economic and environmental consequences of spatial management options. Thus, a number of authors have already addressed the lack of integrated tools to assess the economic and environmental risks of spatial management options (Foley et al. 2010, Tallis et al. 2010, Olsen et al. 2011).

In general, spatial management options can result in 2 types of conflicts, namely conflicts between human activities and the environment and conflicts between different human activities. The former type of conflict requires an assessment of the risks of anthropogenic activities, which vary in their intensities and footprints on ecosystem components that are sensitive to those activities. An increasing number of studies has presented practical approaches for quantifying the impacts of specific human activities or the cumulative impacts of a number of activities on ecosystem components (Halpern et al. 2008, Ban et al. 2010, Foden et al. 2010, Stelzenmüller et al. 2010b). In the context of marine planning, the impact of one human activity on other activities is being studied to a lesser extent. One example is a study by Berkenhagen et al. (2010) in which the cumulative economic impacts for the fisheries sector were analysed in relation to the development of offshore wind energy in the German exclusive economic zone (EEZ). As yet, studies assessing the risks of spatial management options by integrating more than one sector of human activity and by analysing their potential impacts on each other and on ecosystem components are lacking.

Current approaches in land use management for defining and assessing spatial management options encompass, for instance, multi-criteria analyses (MCA) or spatial optimization techniques, such as Pareto optimality (see Kennedy et al. 2008, Polasky et al. 2008 and references therein). While the former ap- proach requires a weighting of management objectives, the latter eliminates the need for the prior specification of weights. Thus, in the marine environment, an increasing number of case studies are concerned with spatial optimization problems, for instance, in relation to the design of networks of marine protected areas (Smith et al. 2008, Martin et al. 2009). GISbased tools, such as Marxan (Watts et al. 2009) or Ecopath (Christensen et al. 2009), are used to find optimal locations based on defined constraints and targets. While those tools can support the development of spatial management options, an evaluation of the risks and consequences of those management options are beyond their capability. However, a spatially explicit assessment of the risks of possible spatial management scenarios and related uncertainies is crucial for the spatial and temporal allocation of human activities, as is regulated in MSP. Thus, the classical method of testing hypotheses provides, in general, a poor basis for environmental management decisionmaking as it lacks the ability to predict the consequences of those hypotheses (Ellison 1996).

Bayesian Belief Networks (BNs) are models that graphically and probabilistically represent correlative and causal relationships among variables and can account for uncertainty (McCann et al. 2006). BNs have been successfully applied to natural resource management to address environmental management problems and to assess the impact of alternative management measures (Varis et al. 1990, Marcot et al. 2001, Nyberg et al. 2006). A recent study by Stelzenmüller et al. (2010a) combined GIS analysis and BNs to support marine planning tasks by assessing 'what if' scenarios for different planning objectives and related management interventions. Following this methodological concept, we developed, in the present paper, an integrated modelling framework to assess the potential consequences of spatial management options in the German EEZ of the North Sea and in adjacent coastal waters. Moreover, the present study aims to test the framework's ability to combine the assessment of the ecological and economic risks of spatial management options in relation to 2 scenarios at the resolution of fishing fleets. Such a characterisation and quantification of risk is a crucial step in an ecological risk assessment framework, which, in general, comprises problem formulation, hazard identification, risk analysis and risk characterisation (Hayes \& Landis 2004, Landis 2004).

The MSP for the German EEZ is legally binding and contains designated preference areas for a number of sectors, except fishing, together with special areas of conservation (Natura2000 sites) (BMVBS 
2009). The plan specifies a number of high level objectives, such as the promotion of offshore wind energy use (installed capacity of 20000 MW by 2030) or the protection of natural resources by avoiding disruptions to and pollution of the marine environment. However, the likely spatial expansion of offshore wind energy development is beyond the boundaries of designated preference areas. Further individual wind farm licenses will be subjected to environmental impact assessments, and fisheries management options are currently being assessed for Natura2000 sites (Pedersen et al. 2010). In spite of the implemented marine spatial plan, this uncertain development of offshore renewables generates a number of future spatial management scenarios with different economic consequences for the sectors involved (Fock 2011b).

Thus, for the study area, we developed an integrated modelling framework combining BNs and GIS to assess the risks of possible spatial management options in relation to 2 scenarios for international fishing fleets, the vulnerability of plaice Pleuronectes platessa to fishing and the revenues generated within the study area. Those scenarios describe: (1) a shift of resource distribution due to environmental change and the assessment of spatial management options under a defined management objective, and (2) the spatial expansion of wind energy development with a related fishing effort allocation and the prediction of ecological and economical risks. Finally, we tested the capability of this approach to support a risk assessment framework in the context of marine spatial management under different baseline conditions and management objectives.

\section{MATERIALS AND METHODS}

\section{BN development}

Our study area comprised the German EEZ of the North Sea with its adjacent coastal waters (Fig. 1). In a

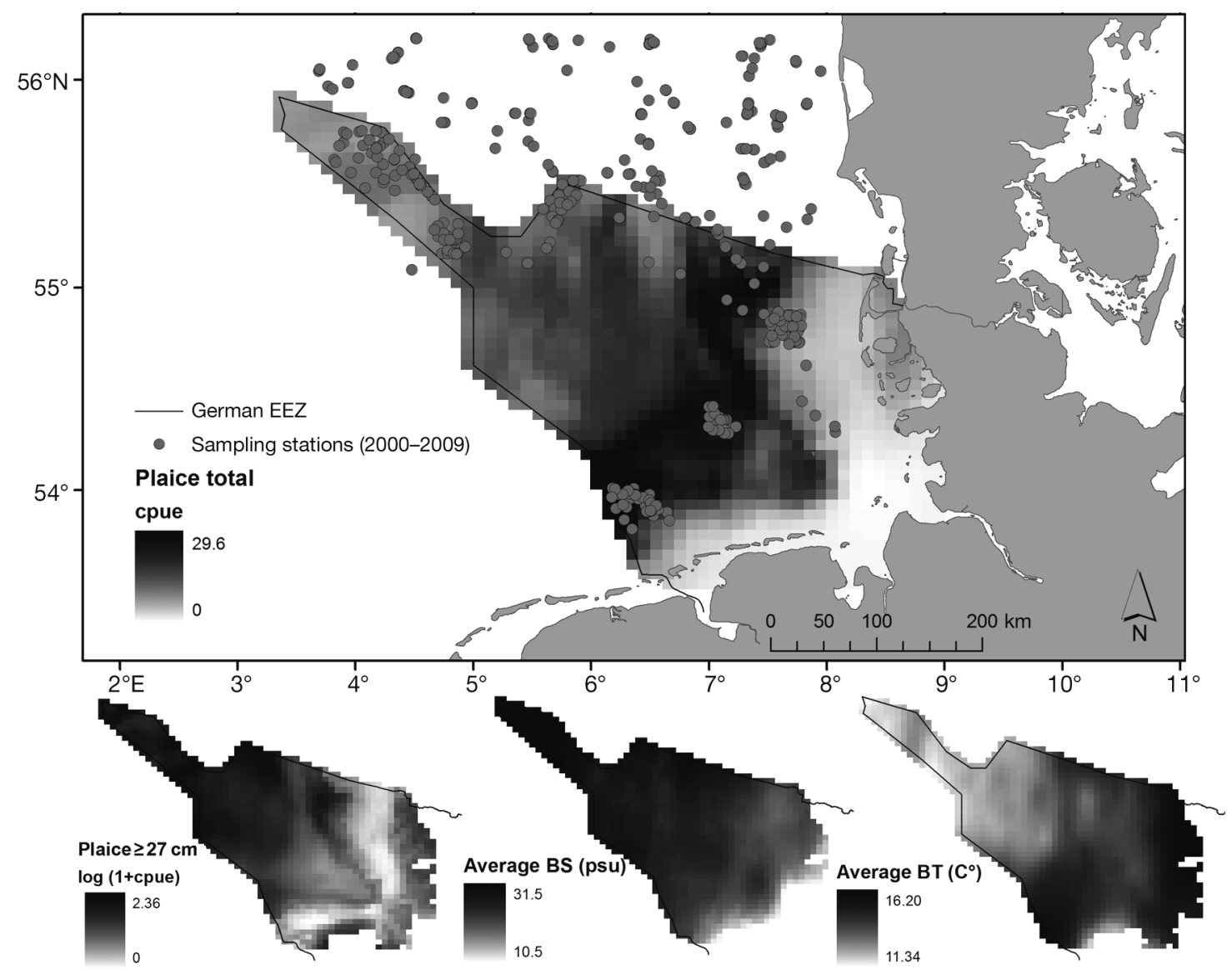

Fig. 1. Study area with $7 \mathrm{~m}$ beam trawl sampling stations, estimated spatial distribution patterns of catch per unit effort (cpue) of total plaice (upper panel), plaice Pleuronectes platessa $\geq 27 \mathrm{~cm}$ (lower, left panel), average (2000-2009) bottom salinity (psu) (lower, middle panel) and temperature $\left(\mathrm{C}^{\circ}\right)$ (lower, right panel). EEZ: exclusive economic zone; BS: bottom salinity; BT: bottom temperature 
GIS we superimposed a 3 by 3 nautical mile (n mile) vector grid for the subsequent analysis. The grid size was determined by the maximum resolution of fishing effort data (see Fock 2008). This grid contained all the attribute information necessary to populate the conditional probability tables (CPTs) of the model nodes (Fig. 2). The model nodes and associated data are described in more detail below (see Table 1).

\section{Average bottom temperature and average bottom salinity}

Bottom temperature and bottom salinity are environmental predictor variables for plaice Pleuronectes platessa. From the ICES oceanographic database (www.ices.dk/ocean/aspx/HydChem/HydChem.aspx) we extracted sea bottom temperature and salinity data for the years from 2000 to 2009 for the third quarter of each year. Within the study area we interpolated the annual temperature and salinity values on a highresolution grid (0.6 n mile or 0.01 decimal degrees), using ordinary kriging (Cressie 1991). We summarised the values on the $3 \mathrm{n}$ mile vector grid to represent average bottom temperature and salinity.

\section{Depth}

The average depth is an environmental predictor variable for plaice. For each grid cell we derived the average depth $(\mathrm{m})$ from the General Bathymetric Chart of the Oceans (GEBCO) digital atlas (www. gebco.net).

\section{Sediment}

We obtained sediment data from the Federal Maritime and Hydrographic Agency and assigned each cell to a sediment type (www.bsh.de). In total, we allocated 17 sediment categories to the grid cells which were comprised of 4 main sediment categories (mud, $\mathrm{M}$; fine sand, $\mathrm{fS}$; medium sand, $\mathrm{mS}_{\text {; }}$ and coarse sand, cS) with different sorting categories ranging from very poorly (vps), poorly (ps), moderately (ms), well (ws) and very well (vws).

\section{PlaiceTotal and Plaice $\geq 27 \mathrm{~cm}$}

For the study area, we extracted plaice catch data from the third quarters of annual beam trawl surveys from 2000 to 2009 (393 tows) using a $7 \mathrm{~m}$ beam trawl with a towing time of $30 \mathrm{~min}$ with the German research vessels 'SOLEA I' and 'SOLEA II' (see Fig. 1). We also extracted, for each sampling station, the bottom temperature and bottom salinity records. With the help of a length-weight relationship ( $w[\mathrm{~kg}]=a$ length $^{b} ; a=0.0069$ and $b=3.1084$; vTI data), we computed catch per unit effort (cpue; kg per $30 \mathrm{~min}$ ) for total plaice catches (referred to as total) and for the size class $\geq 27 \mathrm{~cm}$ (referred to as $\geq 27 \mathrm{~cm}$ ), as $27 \mathrm{~cm}$ corresponds to the minimum landing size of plaice. To account for the inter-annual variability $(\mathrm{p}=0.05)$ in plaice catch data (total and $\geq 27 \mathrm{~cm}$ ), we standardised cpue data with the help of generalized linear models (GLM) using the factor 'year' as a predictor variable. As described in Stelzenmüller et al. (2007), we derived calibration coefficients by back-transforming

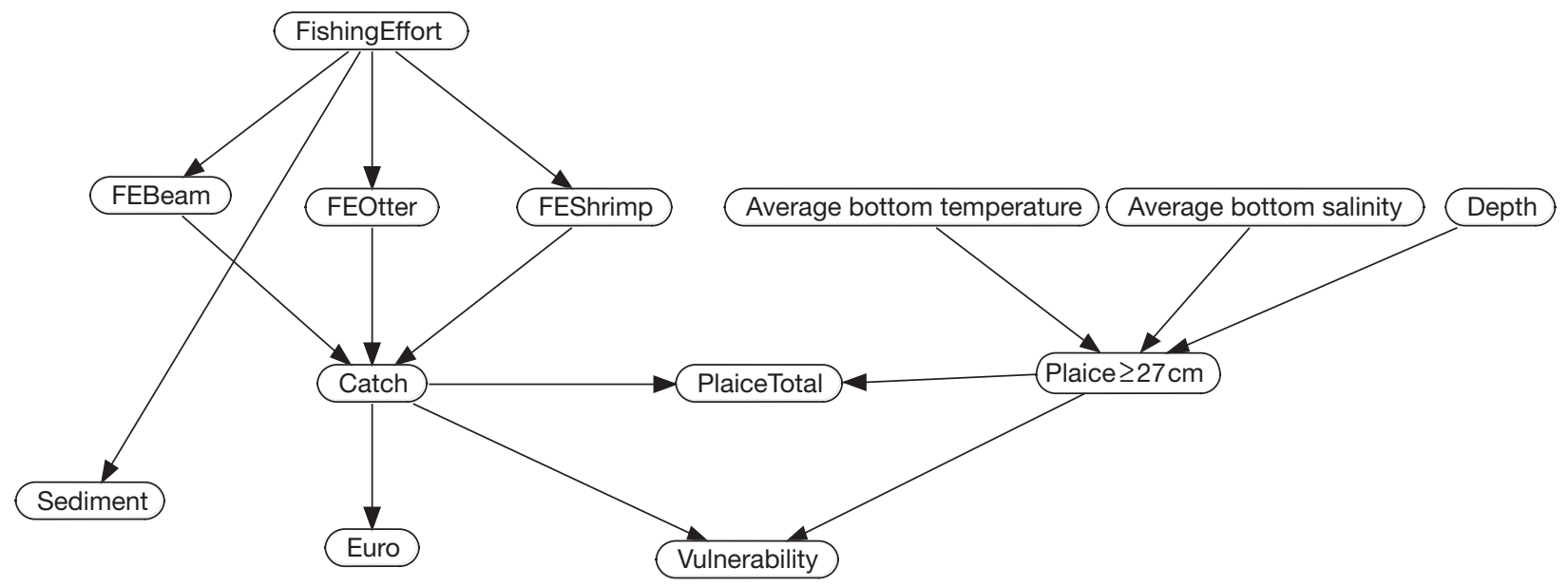

Fig. 2. Conceptual model showing the key variables used to predict the overall level of vulnerability of plaice Pleuronectes platessa to fishing as a function of the total catch and catch per unit effort (cpue) of plaice $\geq 27 \mathrm{~cm}$. Abbreviations defined in Table 1 
Table 1. Overview of model nodes, description of data collection and states. All model nodes reflect attributes from the 3 by $3 \mathrm{n}$ mile vector grid. cpue: catch per unit effort

\begin{tabular}{|c|c|c|}
\hline Node & Description & States \\
\hline FishingEffort & $\begin{array}{l}\text { Sum of total hours fished per } 3 \mathrm{n} \text { mile grid cell in } 2008 \text { by German, } \\
\text { Dutch and Danish beam and otter trawlers potentially catching } \\
\text { plaice Pleuronectes platessa } \geq 27 \mathrm{~cm}\end{array}$ & $\begin{array}{l}0-33 ; 33-100 ; 100-200 \\
200-700 ; 700-3400\end{array}$ \\
\hline FEBeam & $\begin{array}{l}\text { Total hours fished per } 3 \mathrm{n} \text { mile grid cell in } 2008 \text { by German, } \\
\text { Dutch and Danish beam trawlers }\end{array}$ & $\begin{array}{l}0-0.4 ; 0.4-6 ; 6-30 ; 30-110 ; \\
110-1330\end{array}$ \\
\hline FEOtter & $\begin{array}{l}\text { Total hours fished per } 3 \mathrm{n} \text { mile grid cell in } 2008 \text { by German, } \\
\text { Dutch and Danish otter trawlers with a mesh size } \geq 80 \mathrm{~mm}\end{array}$ & $0 ; 0-1.9 ; 1.9-5 ; 5-17 ; 17-575$ \\
\hline FEShrimp & $\begin{array}{l}\text { Total hours fished per } 3 \mathrm{n} \text { mile grid cell in } 2008 \text { by German, } \\
\text { Dutch and Danish beam trawlers fishing for brown shrimp } \\
\text { with a mesh size } 16-31 \mathrm{~mm}\end{array}$ & $\begin{array}{l}0 ; 0-1.3 ; 1.3-3.9 ; 3.9-16 ; \\
16-414\end{array}$ \\
\hline Catch & $\begin{array}{l}\text { Total German, Dutch and Danish landings }(\mathrm{kg}) \text { of plaice } \geq 27 \mathrm{~cm} \\
\text { in } 2008 \text { per } 3 \mathrm{n} \text { mile grid cell derived from logbook data }\end{array}$ & $\begin{array}{l}0-40 ; 40-500 ; 500-2500 \\
2500-7000 ; 7000-44000\end{array}$ \\
\hline Euro & $\begin{array}{l}\text { Total catch of plaice } \geq 27 \mathrm{~cm} \text { multiplied by the average market } \\
\text { price per } \mathrm{kg} \text { in } 2008(1.89 €)\end{array}$ & $\begin{array}{l}0-80 ; 80-1100 ; 1100-5000 ; \\
5000-13000 ; 13000-90000\end{array}$ \\
\hline Sediment & $\begin{array}{l}\text { Sediment data obtained from the Bundesamt für Seeschifffahrt und } \\
\text { Hydrographie (Federal Maritime and Hydrographic Agency, } \\
\text { www.bsh.de) with } 17 \text { sediment categories: mud (M), fine sand (fS), } \\
\text { medium sand (mS) and coarse sand (cS) with different sorting cate- } \\
\text { gories ranging from very poorly (vps), poorly (ps), moderately (ms), } \\
\text { well (ws) and very well (vws) sorted }\end{array}$ & $\begin{array}{l}\text { Sms, cSvws, cSws, fSms, fSps, } \\
\text { fSvps, fSvws, fSws, Mms, } \\
\text { Mps, mSms, mSvps, mSvws, } \\
\text { mSws, Mvps, Mvws, Mws }\end{array}$ \\
\hline $\begin{array}{l}\text { Average bottom } \\
\text { temperature }\end{array}$ & $\begin{array}{l}\text { Annual bottom temperature }\left(\mathrm{C}^{\circ}\right) \text { distributions (www.ices.dk) were } \\
\text { estimated with ordinary kriging (Cressie 1991) and averaged from } \\
2000 \text { to } 2009 \text { for each } 3 \mathrm{n} \text { mile grid cell }\end{array}$ & $\begin{array}{l}11.3-12.7 ; 12.7-13.7 ; \\
13.7-14.3 ; 14.3-15 ; 15-16.3\end{array}$ \\
\hline $\begin{array}{l}\text { Average bottom } \\
\text { salinity }\end{array}$ & $\begin{array}{l}\text { Annual bottom salinity (psu) distributions (www.ices.dk) were } \\
\text { estimated with ordinary kriging (Cressie 1991) and averaged from } \\
2000 \text { to } 2009 \text { for each } 3 \mathrm{n} \text { mile grid cell in every grid }\end{array}$ & $\begin{array}{l}10.5-24.2 ; 24.2-26.2 ; 26.2-28 \\
28-29.2 ; 29.2-31.5\end{array}$ \\
\hline Plaice $\geq 27 \mathrm{~cm}$ & $\begin{array}{l}\text { Log }(\text { cpue }+1) \text { of plaice } \geq 27 \mathrm{~cm} \text { per } 3 \mathrm{n} \text { mile grid cell predicted with re- } \\
\text { gression kriging (Hengl et al. 2007) using aggregated and standardi- } \\
\text { sed } 7 \mathrm{~m} \text { beam trawl catch data }(2000-2009 \text {, third quarter of each year) }\end{array}$ & $\begin{array}{l}0-0.6 ; 0.6-0.9 ; 0.9-1.4 ; \\
1.4-1.8 ; 1.8-2.4\end{array}$ \\
\hline PlaiceTotal & $\begin{array}{l}\text { Cpue of plaice per } 3 \mathrm{n} \text { mile grid cell predicted with regression kriging } \\
\text { (Hengl et al. 2007) using aggregated and standardised } 7 \mathrm{~m} \text { beam } \\
\text { trawl catch data (2000-2009, third quarter of each year) }\end{array}$ & $0-4 ; 4-8 ; 8-11 ; 11-15 ; 15-30$ \\
\hline Vulnerability & $\begin{array}{l}\text { A relative measure of the vulnerability of plaice } \geq 27 \mathrm{~cm} \text { to beam and } \\
\text { otter trawling within the study area defined as: } \\
\frac{\text { cpue }_{i}}{\sum_{i=1}^{\mathrm{n}} \text { cpue }} / \frac{\text { Total catch }}{\sum_{i=1}^{\mathrm{n}} \text { Total catch }} \\
\text { with the first term reflecting the modelled relative proportion of } \\
\text { plaice } \geq 27 \mathrm{~cm} \text { (log } 1+\text { cpue) within a grid cell }(i) \text { and the second term } \\
\text { showing the relative proportion of the total catch within a grid cell }\end{array}$ & $\begin{array}{l}0 \text { (State } 0, \text { no); }>10.12 \text { (State } 1, \\
\text { very low); 3.45-10.12 (State 2, } \\
\text { low); } 1.67-3.45 \text { (State } 3, \text { medi- } \\
\text { um); } 0.38-1.67 \text { (State } 4 \text {, high); } \\
<0.38 \text { (State 5, very high) }\end{array}$ \\
\hline Depth & $\begin{array}{l}\text { The average depth (m) for each grid cell was derived from the } \\
\text { General Bathymetric Chart of the Oceans (GEBCO) digital atlas } \\
\text { (www.gebco.net) }\end{array}$ & $\begin{array}{l}12-26 ; 26-36 ; 36-40.4 \\
40.4-44 ; 44-72\end{array}$ \\
\hline
\end{tabular}

the parameter estimates (Quinn II \& Deriso 1999) and transformed cpue data by dividing the raw cpue by the appropriate power coefficient (exponential function of GLM parameter estimate). We predicted the average (2000 to 2009) spatial distribution pattern of plaice with standardised and aggregated cpue data with the help of regression kriging, a hybrid technique which combines regression techniques with kriging of the regression residuals (see details of the method in Hengl et al. 2007). Recent studies used this modelling technique to estimate the spatial distribution pattern of commercial species such as plaice, sole Solea solea and thornback ray Raja clavata (Maxwell et al. 2009) or patterns of fishing effort density around marine protected areas (Stelzenmüller et al. 2008). This spatial modelling technique requires a number of analysis steps. First, we assessed the relationships between the cpue data of plaice (total and $\geq 27 \mathrm{~cm}$ ) and the environmental variables at the sampling locations using generalized additive models (GAMs) 
(Hastie \& Tibshirani 1986). We assessed possible colinearity with the help of Pearson product moment correlation between the cpue data and the environmental variables (average bottom temperature, average bottom salinity and depth) and among the environmental variables. For the GAM calculations, we allowed for possible non-linear effects of the environmental variables using natural splines (Venables \& Dichmont 2004) while controlling the risk of overfitting by limiting the degrees of freedom. From the full set of calculated GAMs, we selected the best models by the lowest value of the Akaike information criterion (Akaike 1973) and predicted the cpue of total plaice and plaice $\geq 27 \mathrm{~cm} \log (1+\mathrm{cpue})$ for each grid cell of a high-resolution grid (0.6 n mile) (referred to as trend maps). We corrected the spatial GAM estimates by conducting a geostatistical analysis of the GAM residuals, which is the second step in the regression kriging process. We described the spatial structuring of the GAM residuals using semivariograms and fitted the parameters of spherical models (nugget effect, sill and range) with a weighted leastsquares fitting procedure (Cressie 1991). Afterwards, we predicted a value of the residuals using ordinary point kriging for each $0.6 \mathrm{n}$ mile grid cell (referred to as autocorrelation map). We then combined the respective trend and autocorrelation maps to produce continuous maps of the average distribution of plaice. In a final step, we transferred the predicted cpue of plaice (total and $\geq 27 \mathrm{~cm}$ ) to our standard analysis grid (3 n mile) within the GIS.

\section{FishingEffort, FEBeam, FEOtter and FEShrimp}

We combined German, Dutch and Danish VMS (vessel monitoring system) and logbook data from 2008 to calculate fishing effort and total catch (marketable catch) within in each $3 \mathrm{n}$ mile grid cell. Logbook data are not defined on these fine levels, but it is a proportional calculation to effort (see below). Original VMS data consist of the vessel identification number, position, speed and heading. We assessed the fishing effort for métiers (fleets) which catch plaice $\geq 27 \mathrm{~cm}$ as target species and bycatch; these comprised beam trawls fishing for brown shrimp with a mesh size of from 16 to $31 \mathrm{~mm}$ (referred to as FEShrimp), beam trawls with a mesh size of from 80 to $99 \mathrm{~mm}$ targeting flatfish (referred to as FEBeam) and demersal otter board fishing for flatfish with a mesh size of from 80 to $99 \mathrm{~mm}$ (referred to as FEOtter). We also aggregated the total fishing effort of those fleets (referred to as FishingEffort). We categorised the VMS data into sig- nals indicating 'fishing' and 'not fishing' with the help of the individual vessel speed. The position of each vessel was then allocated to the $3 \mathrm{n}$ mile grid cells (i.e. 100 fine rectangles per ICES rectangle), and the time interval between 2 positions was summed up to the amount of fishing effort spent per grid cell (hours fishing). Since the time interval between each position can be up to $2 \mathrm{~h}$, there is a considerable amount of 'unseen' activity by each vessel. We took this uncertainty into account following the method developed by Fock (2008), whereby each registration was substituted with a discrete set of positions with a high probability of vessel presence.

\section{Catch and Euro}

We derived the total catch from plaice landings indicated in the logbook data. We aggregated landings according the international VMS data and calculated the total catch $(\mathrm{kg})$ for 2008. The total catch was distributed proportionally to the effort to each $3 \mathrm{n}$ mile grid cell and multiplied by the mean price (1.89 €) of plaice of German landings in 2008 to calculate the revenue (referred to as Euro) gained per grid cell.

\section{Vulnerability}

To reflect the pressure of the fishing activities on the plaice population, we constructed a measure of vulnerability which reflects, at a given location, the relative local pressure of fishing on the resource in relation to its estimated spatial distribution. Thus, we defined the vulnerability ( $V$ ) of plaice $\geq 27 \mathrm{~cm}$ to fishing as:

$$
V_{i}=\frac{\text { cpue }_{i}}{\sum_{i=1}^{\mathrm{n}} \text { cpue }} / \frac{\text { Total catch }_{i}}{\sum_{i=1}^{\mathrm{n}} \text { Total catch' }^{\prime}}
$$

with the first term reflecting the ratio of cpue on plaice $\geq 27 \mathrm{~cm}$ ( $\log 1+$ cpue) within a single grid cell $i$ and the cpue cumulated over all cells. These cpue data refer to surveys and therefore better represent the abundance. The second term indicates the same ratio for commercial catches. The lower the coefficient is, the higher the vulnerability for plaice $\geq 27 \mathrm{~cm}$. We then categorised the vulnerability values to 6 vulnerability states using quartiles: State $0=$ no; State $1(>10.18)=$ very low; State $2(3.45$ to 10.18$)=$ low; State 3 (1.67 to 3.45) = intermediate; State 4 (0.38 to 1.67$)=$ high; State $5(0.04$ to 0.4$)=$ very high.

Our vulnerability index $V_{i}$ reflects the overlap of population and catches, but it can also be interpreted 
in terms of fishing mortality:

$$
V_{i}=\frac{\text { cpue }_{i}+\sum_{i=1}^{\mathrm{n}} \text { Total catch }}{\sum_{i=1}^{\mathrm{n}} \text { cpue } \times \text { Total catch }}
$$

as:

$$
V_{i}=p_{\text {plaice }, i} \times F_{\text {plaice }} \times \frac{1}{f_{i}}
$$

with $p_{\text {plaice, } i}$ being the occurrence of plaice within a cell, $F_{\text {plaice }}$ as the fishing mortality for the entire stock and $f_{i}$ as the local fishing mortality (Rijnsdorp et al. 2006).

We used the Netica software system (www.norsys. com) (see details in Spiegelhalter \& Dawid 1993 on the inference algorithm implemented in Netica) to develop the BN model and combined the in- and output files with the GIS vector grid. The BN model (Fig. 2) represents the vulnerability of plaice $\geq 27 \mathrm{~cm}$ to fishing and the revenues generated from plaice catches within the study area as a function of fishing effort and the average distribution pattern of the resource, which is, in turn, influenced by the environmental variables bottom temperature, bottom salinity and depth. Fishing effort and the environmental variables are parent nodes and are considered to be independent of each other. Each parent node has different discrete states (e.g. temperature or depth categories) with an associated probability of occurrence. The FEBeam, FEOtter and FEShrimp, reflecting the fishing effort (hours fished) of the different métiers, are child nodes of the fishing effort node. Further, the vulnerability node is defined as a child node of the total catch node and the resource node (plaice $\geq 27 \mathrm{~cm}$ ). The revenue node is a child node of the total catch node. The child node total plaice is influenced by the total catch node and the plaice $\geq 27 \mathrm{~cm}$ node, while the sediment node showing the sediment categories affected by fishing is a child node of the fishing effort node.

One of the advantages of using BNs is that empirical data, as well as expert opinion, can be used to define the prior probabilities. For the present study, however, we built the prior probabilities for each node in our model based on GIS data and not on expert opinion. Thus, the model reflects the current level of 'evidence' for relationships, and the data were used to populate the conditional probability tables (CPTs).

\section{BN sensitivity and performance assessment}

We conducted a sensitivity analysis and assessed the overall performance of the BN. First, we evalu- ated the sensitivity of the vulnerability node to the influence of the parent nodes by calculating the variance reduction (Marcot et al. 2006). Next, we tested the performance of the model by removing the observations for the vulnerability node and a subsequent calculation of the maximum-likelihood state. This allowed us to estimate the Type I error rate (\%) by comparing the predicted beliefs of the unobserved vulnerability node with the true values for the vulnerability node and to evaluate the classification success rate using the spherical payoff index (see detailed description in Marcot et al. 2006):

$$
\text { MOAC } \frac{P_{\mathrm{c}}}{\sqrt{\sum_{j=1}^{\mathrm{n}} P_{j}^{2}}}
$$

where MOAC is the mean probability value of a given state averaged over all cases and ranges from values of 0 to 1 ( 1 being the best model performance), $P_{\mathrm{C}}$ is the probability predicted for the correct state, $P_{j}$ is the probability predicted for state $j$ and $n$ is the number of states.

\section{Marine management scenarios}

With the help of the BN-GIS framework we explored possible management options under a defined management objective in case of environmental change and assessed potential consequences of a spatial management scenario for the fishing fleets, the vulnerability of the plaice population and the revenues in the area of interest. Thus, after building and testing the $\mathrm{BN}$ as described above, we used it to infer the behaviour and response of the variables to different scenarios. We defined 2 marine management scenarios which included the setting of objectives and predicted the consequences of those objectives. We defined the current state as the baseline or 'do-nothing' scenario.

\section{Scenario 1}

What management targets for fisheries are required to maintain the current vulnerability of plaice in the case of environmental change? We defined the maintenance of the current average vulnerability of plaice to fishing as the management objective. We simulated an increase in the relative average bottom temperature in our study area of $0.5^{\circ} \mathrm{C}$ with now $10 \%$ of the area being in State 1, $12 \%$ in State 2, $13.7 \%$ in State 3, 31.4\% in State 4 and $32.9 \%$ in State 5. We then predicted the responses of the variables and 
the potential consequences for the vulnerability of plaice. Afterwards we used the $\mathrm{BN}$ model to predict a possible management intervention for the total fishing effort to maintain the current average measure of vulnerability of marketable plaice.

\section{Scenario 2}

How does the vulnerability of marketable plaice change after the development of offshore wind energy and a related displacement of fishing effort? One of the high level German management objectives for the EEZ of the North Sea is an installed capacity of offshore wind energy of $20000 \mathrm{MW}$ by 2030. We used the current application areas for wind energy development (provided by the Bundesamt für Seeschifffahrt und Hydrographie [BSH]; www.bsh.de) and reallocated the current fishing effort with the help of a set of simplified displacement rules (see Fig. 3). Although fishermen's behaviour is likely much more complex, we reset the fishing effort for grid cells within the wind energy application areas to zero and redistributed the same amount of fishing effort. In the GIS we constructed 3 buffer rings $(3,10$ and $15 \mathrm{~km})$ around the application areas and redistributed the fishing effort of each fleet with $70 \%$ of the respective effort to the $3 \mathrm{~km}$ buffer area, $20 \%$ to the $10 \mathrm{~km}$ buffer area and $10 \%$ to the 15 $\mathrm{km}$ buffer area. Further cells where no fishing activity occurred in 2008 were excluded from the redistribution of activities. This displacement scenario should account for the fact that fishermen tend to fish very close to closed areas such as marine protected areas or fishing closures (e.g. Murawski et al. 2005, Stelzenmüller et al. 2008).

\section{RESULTS}

\section{Baseline scenario}

The complete derived model describing the relationships between fishing effort, total catch of plaice,
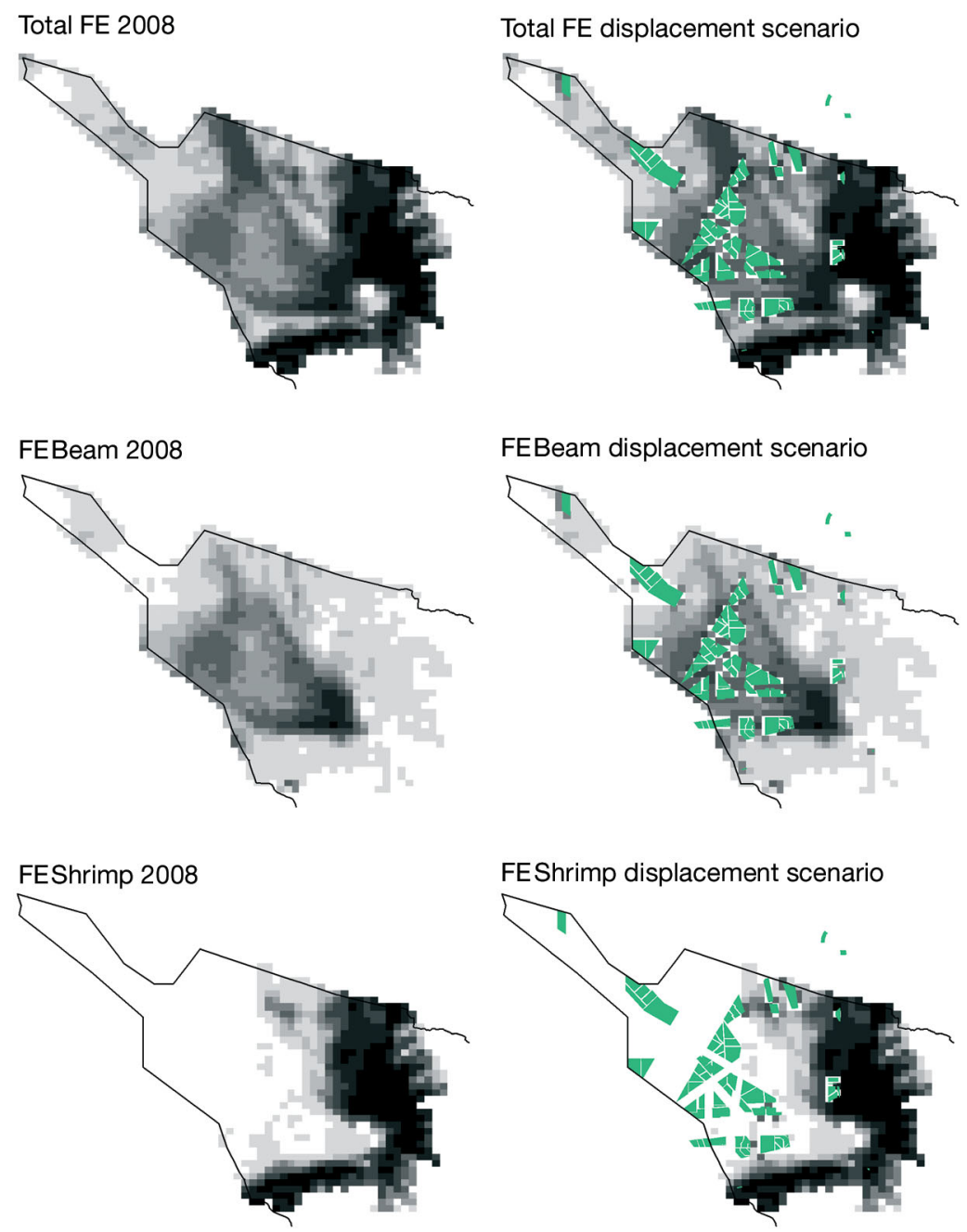

FEShrimp displacement scenario

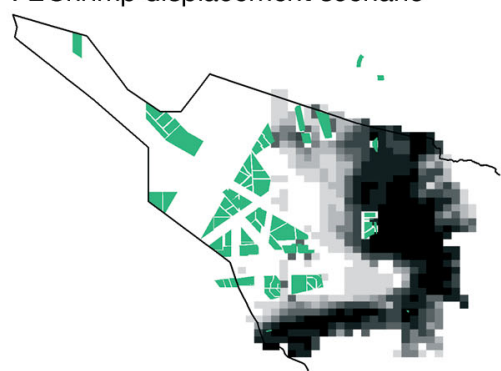

Wind farm application areas Fishing effort (h)
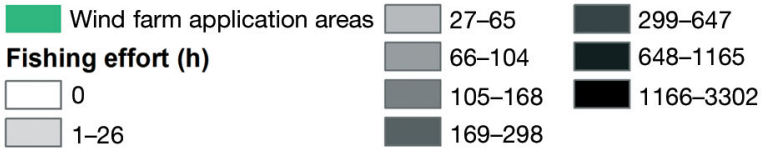

Fig. 3. Spatial distribution patterns of the total international fishing effort (FE) in 2008 of the beam trawl fleet (FEBeam) and shrimper fleet (FEShrimp) (left panels) and respective fishing effort displace-ment scenarios (right panels)

environmental parameters and the distribution of the resource is presented in Fig. 4. For each node representing a continuous variable a weighed mean (the mean value weighted by the probability of occurrence) and a Gaussian standard deviation is shown. Thus, we computed an expected mean of $546 \mathrm{~h}$ fished in total by international fishing fleets. Also $20.2 \%$ of the surface area has been fished from 0 to $33 \mathrm{~h}$ in total by international fishing fleets. The baseline scenario also revealed that there is a $19.4 \%$ chance of catching from 0 to $40 \mathrm{~kg}$ of plaice $\geq 27 \mathrm{~cm}$ within any given grid cell. The revenue node (Euro) showed that there is a 
$22.2 \%$ chance that any given gird cell would generate between 80 and $1100 €$ from German plaice landings in 2008. The expected revenue was $12100 €$ with a standard deviation of $21000 €$. A further $42.8 \%$ of the fishing activities took place on very well sorted fine sand (fSvws) and $26.5 \%$ took place on well sorted fine sand (fSws). Under current fisheries management and the predicted spatial distribution of the resource, we computed a likelihood of $8.4 \%$ that a grid cell experienced a vulnerability of 0 (State 0 ) and a $26.4 \%$ chance of being in the vulnerability State 4 (high).

\section{BN sensitivity and performance assessment}

Table 2 shows the results of the sensitivity assessment of the BN model as the computed variance reduction for the vulnerability node. The total catch of plaice had the greatest influence followed by the revenue of plaice. The revenues ranked high due to the significant correlation with the catch values. Interestingly, the fishing effort of the beam trawlers reduced the variance by $9.4 \%$, while the total fishing effort reduced the latter by only $3.92 \%$. The environmental variables were the least influential ones. The calculation of the Type I error rate revealed a slightly increased value of $25.6 \%$ for the vulnerability node. However, the classification success rate (spherical payoff), which ranges from 0 to 1 , with 1 being best model performance, indicated a relatively accurate model for predicting vulnerability with a value of 0.8 . The confusion matrix provided in Table 3 indicates the accuracy of the beliefs of the vulnerability node predicted by the BN model using the data described in Table 1.

\section{Scenario 1}

The consequences of the simulated increase in weighted average bottom temperature from 13.9 to $14.4^{\circ} \mathrm{C}$ are displayed in Fig. 5a. Under this environ-
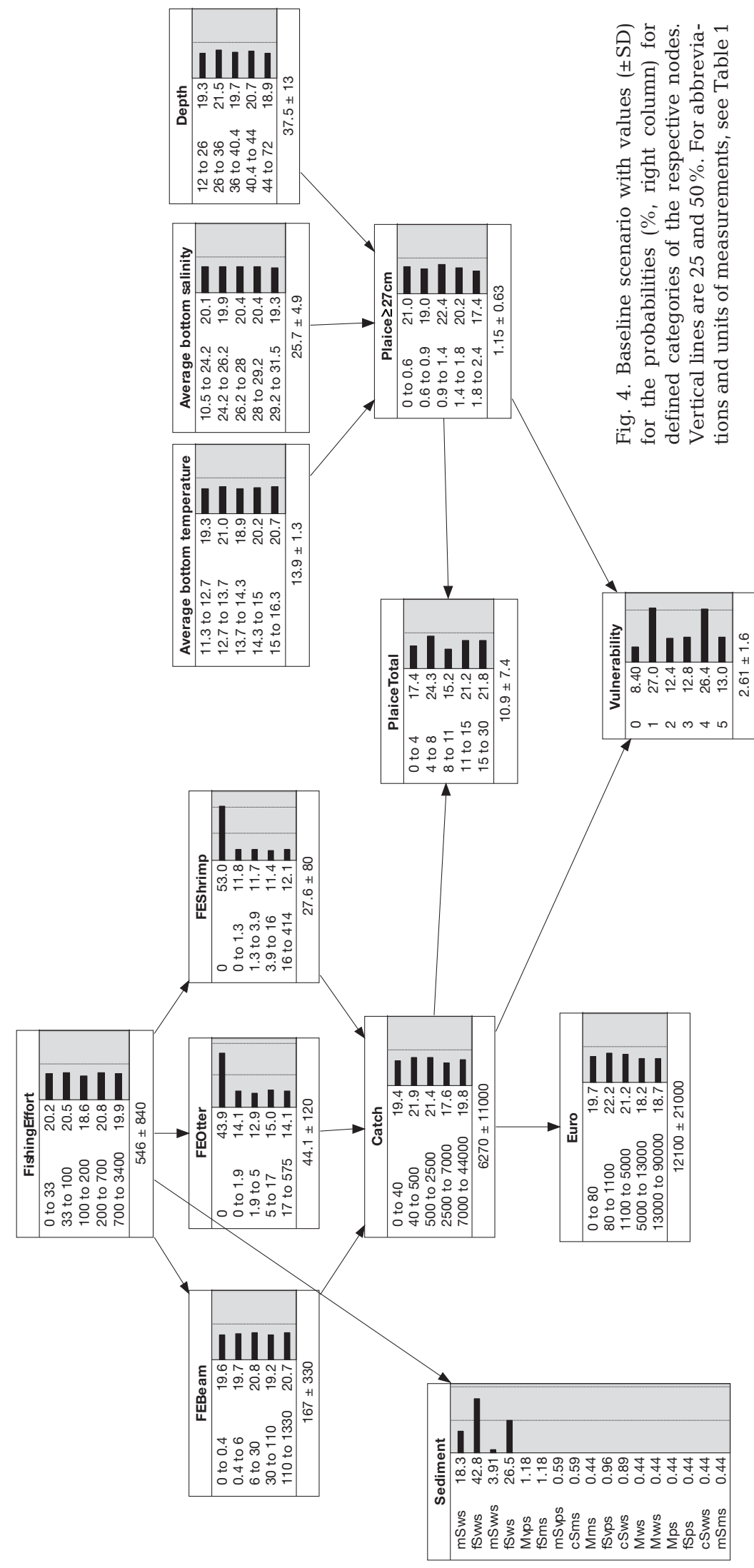
Table 2 . The variance reduction reflects the sensitivity of the vulnerability node to the findings of the parent nodes. For abbreviations, see Table 1

\begin{tabular}{|lc|}
\hline Node & Variance reduction (\%) \\
\hline Catch & 57.50 \\
Euro & 54.10 \\
PlaiceTotal & 14.20 \\
FEBeam & 9.43 \\
FishingEffort & 3.92 \\
Plaice $\geq 27 \mathrm{~cm}$ & 2.39 \\
FEOtter & 2.06 \\
FEShrimp & 0.84 \\
Sediment & 0.18 \\
Average bottom temperature & 0.17 \\
Average bottom salinity & 0.17 \\
Depth & 0.07 \\
\hline
\end{tabular}

mental change scenario the weighted average vulnerability for plaice increased slightly from 2.61 to 2.64 caused by a marginal decrease in surface area (or number of cells) in the vulnerability States 0, 2, 3 and 4 and a concurrent increase in surface area in States 1 and 5. This increase in the average vulnerability is not significant as it is still within the confidence limit of the standard deviation. However, under the management objective of maintaining the current expected value of vulnerability, one possible management intervention would be to increase the surface area (or number of cells) in fishing effort State 1 by $20 \%$ and State 2 by $16 \%$, together with a reduction of the surface area in fishing effort State 3 by $8 \%$ and States 4 and 5 by approximately $14 \%$ (see Fig. 5b). This possible intervention reflects a reduction of the weighted average international total annual hours fished per grid cell (equals $30 \mathrm{~km}^{2}$ ) by $60 \%$ (from 546 to $197 \mathrm{~h}$ ), with the FEBeam being affected most (from 167 to $87 \mathrm{~h}$ ). The consequences for revenues would be a possible decrease in the expected mean catch by 840 to $5430 \mathrm{~kg}$, with an associated decrease in mean revenue per grid cell area of $1500 €$ (given constant prices).

Table 3. Confusion matrix showing the accuracy of the beliefs of the vulnerability node predicted by the Bayesian Belief Network (BN) model using the data described in Table 1

\begin{tabular}{|lrrrrrr|}
\hline $\begin{array}{l}\text { Actual vulne- } \\
\text { rability state }\end{array}$ & State 0 & State 1 & State 2 & State 3 & State 4 & State 5 \\
\hline 0 & 22 & 31 & 0 & 0 & 0 & 0 \\
1 & 4 & 279 & 28 & 0 & 0 & 0 \\
2 & 0 & 7 & 177 & 2 & 0 & 0 \\
3 & 0 & 1 & 110 & 13 & 61 & 0 \\
4 & 0 & 0 & 19 & 9 & 345 & 2 \\
5 & 0 & 0 & 4 & 0 & 41 & 91 \\
\hline
\end{tabular}

\section{Scenario 2}

The BN model predicted the beliefs for all states of the total catch and vulnerability nodes based on the defined fishing effort reallocation after the closure of the wind farm application areas to fishing (Fig. 6). The predicted distribution of the catches showed a rather homogenous increase of catches around the areas closed for fishing. The arithmetic mean of catches under Scenario 2 is approximately $3000 \mathrm{~kg}$ higher than under the baseline scenario. The predicted pattern of the most probable vulnerability states showed a decrease in the surface area in the vulnerability State 5 and an increase in the surface area in States 2 and 4. A closer examination of the spatial distribution patterns of predicted vulnerability states showed, for instance, for State 2 a general increase in the number of cells in the north-eastern part of the study area under Scenario 2 (Fig. 7). In Fig. 8 the surface area per vulnerability state is compared between the baseline scenario and Scenario 2 . Thus, the predicted consequences or costs of Scenario 2 were that $12 \%$ of the surface area would experience an impairment of vulnerability. In contrast, the benefit would be that approximately $17 \%$ of the surface area would experience a lower level of vulnerability compared to the baseline scenario and $71 \%$ of the surface area would not experience any change.

\section{DISCUSSION}

We assessed the risks of possible spatial management options for the vulnerability of plaice Pleuronectes platessa to fishing and the fisheries' economic viability in the German EEZ of the North Sea and its adjacent coastal waters in relation to 2 scenarios. In the context of a risk assessment framework the spatial predictions of plaice cpue, fishing effort, total catch and revenue, and plaice vulnerability correspond to the risk analysis step, where the likelihood of the exposure to a hazard and its likely effects are described.

Our spatial models of plaice cpue represent only average estimates of the plaice distribution in the third quarter of each year between 2000 and 2009, and the data on fishing effort are only from 2008; thus, the results are limited to a relative interpretation. However, they suffice for 


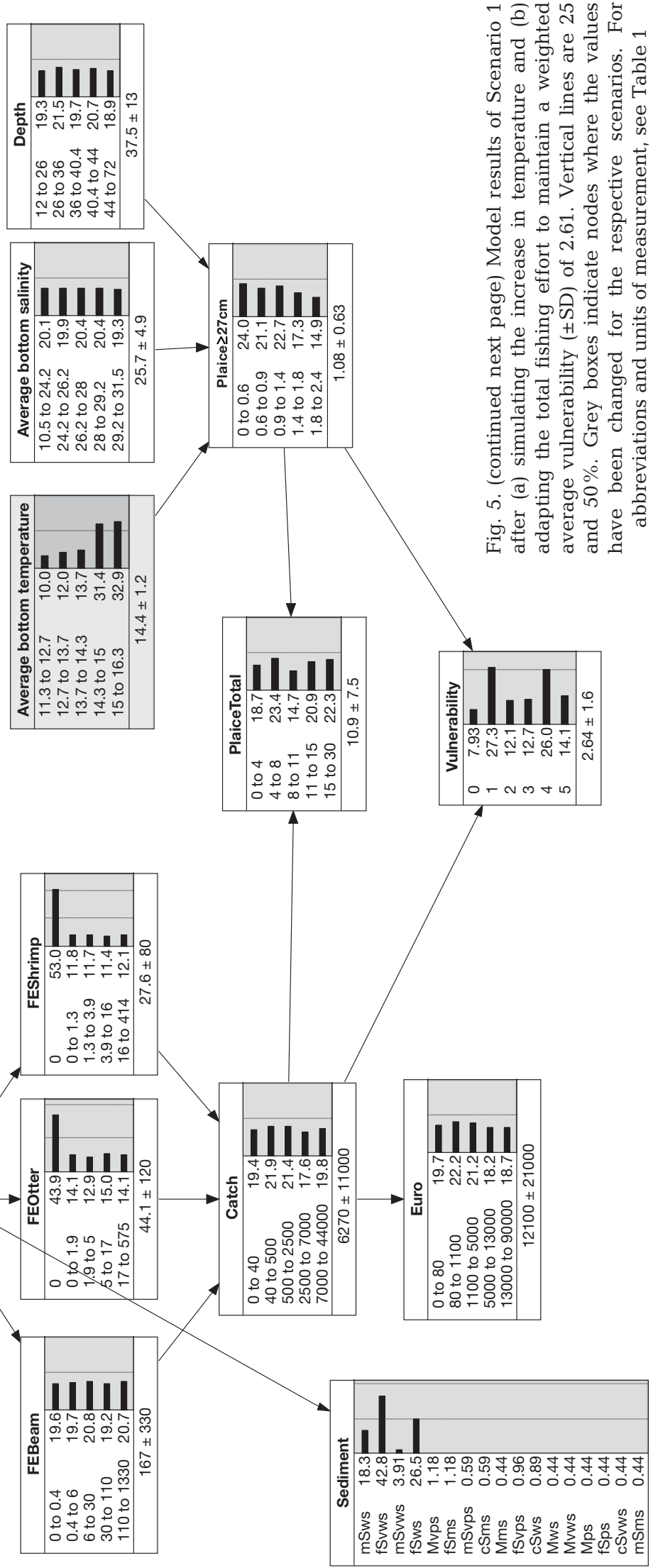

constructing a measure of the relative vulnerability of plaice to fishing as an indicator of the sensitivity of an ecosystem component to human pressures. Here, we followed the general concept of vulnerability reflecting the ratio between an effect indicator and an exposure indicator (see a detailed review by De Lange et al. 2010 of the methods to assess sensitivity and vulnerability). Recent studies by Fock (2011a) and Fock et al. (2011) showed that such a measure of vulnerability (i.e. the risk of an ecosystem component) can also be expressed as a relative measure accounting for the negative and positive effects of disturbance such as fishing.

Our presented measure of vulnerability does not reflect the condition of the plaice population and its general vulnerability to fishing, instead it reflects a static measure built on the ratio of 2 proportions. As already indicated, our proposed spatial $V_{i}$ can also be interpreted in relation to fishery mortality, allowing for a more general assessment of vulnerability of fish populations to fishing. Thus, the vulnerability index $V_{i}$ may be applied in cases where full ecological risk analysis cannot be parameterised. It may also be applied to stocks for which analytical assessments are not available.

We presented 2 different scenarios to test the capability of our approach to assess the consequences of spatial management options and to resolve those risks spatially. In other words, such an assessment corresponds to the risk characterisation step of a risk assessment framework. The first scenario simulated an increase in the average bottom temperature of $0.5^{\circ} \mathrm{C}$ and showed one possible management option under the management objective of maintaining the expected average vulnerability. Although this scenario reflects a rather hypothetical set up, the results highlighted the importance of specifying the management regulations of fishing activities 


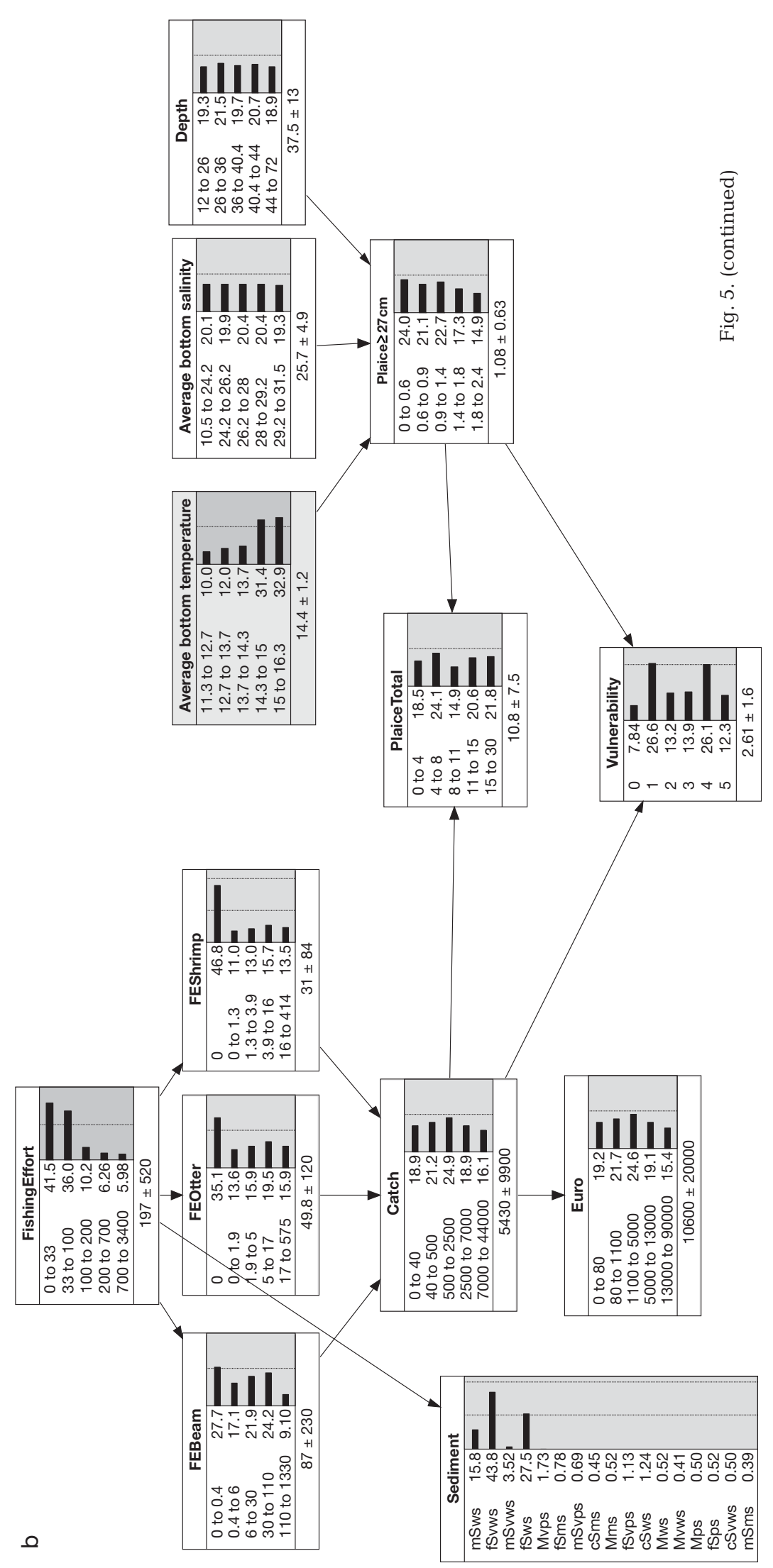

on the level of fishing fleets. In our example, the beam trawl fleet was affected most by the overall restriction of the annual hours fished. In addition, different fishing activities have different impacts on the environment, which is, in turn, the result of the catchability of the gear used and its bottom contact (Fock et al. 2011). The scenario results also revealed changes in the relative magnitude of pressure on the different sediment categories due to changes in fishing effort. Hence, future applications of the BN model could also explore scenarios of potential management measures to achieve multiple management objectives, such as the reduction of pressure on certain sediment categories (which may reflect certain benthos communities) and the prevention of a certain state of plaice vulnerability. In addition to a spatial shift in plaice distribution, other expected impacts of such an environmental change scenario may be seen in a shift in fishing seasons due to possible changes in the spawning behaviour of plaice (Munk et al. 2009). Although the effects of increasing temperatures since 1989 on the quality of plaice nursery grounds are not clear, possible impacts may comprise a mismatch of benthic production and energy requirements of 0 -group flatfish (Teal et al. 2008). Thus, the international fleet targeting plaice in the study area would need to adapt to such changes. Leaving aside any potential implication on fishing costs, the economic consequences of changes in seasonality will most likely influence supply and demand dynamics and therefore prices and revenues. Thus, this scenario could be used further to explore the effects of management options on the level of fishing fleets and to identify adaptation options when pressures are added that cannot be managed, such as climate change.

Our second scenario was explicitly designed to test the framework's capability for supporting the decision-making process in marine spatial manage- 
Baseline scenario

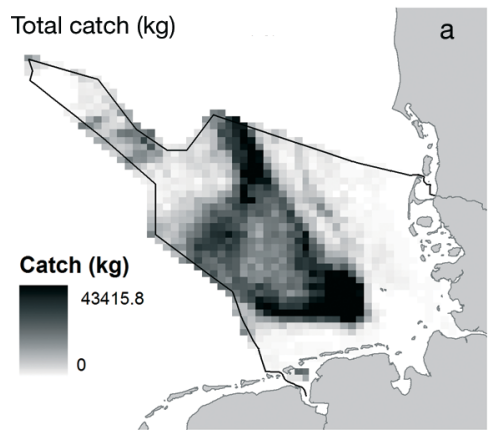

Vulnerability plaice $\geq 27 \mathrm{~cm}$

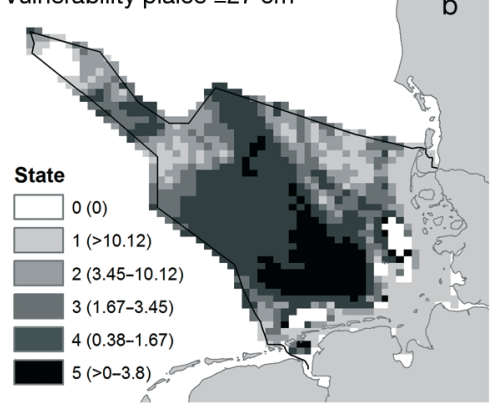

Scenario 2

Estimated total catch $(\mathrm{kg})$

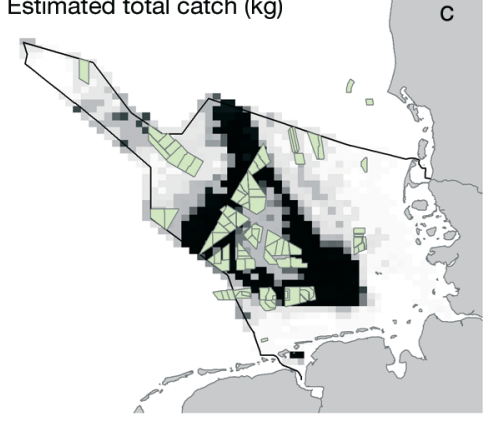

Most probable vulnerability state

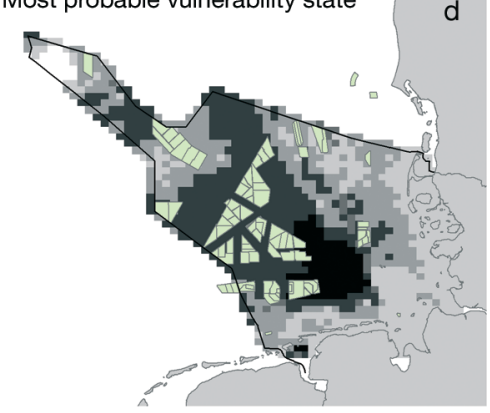

Fig. 6. (a) Total catch (kg) derived from vessel monitoring system and logbook data in 2008, (b) current vulnerability of plaice $\geq 27 \mathrm{~cm}$ to fishing pressure, (c) the predicted distribution of total catch and (d) the most probable vulnerability state of plaice $\geq 27 \mathrm{~cm}$ after the displacement of fishing effort (Scenario 2) due to implementation of offshore wind farms (green in $\mathrm{c}, \mathrm{d}$ )

ment. We used the current application areas for offshore wind farms as a basis for reallocating the international fishing effort which occurred in those areas in 2008. A recent study by Berkenhagen et al. (2010) estimated that the flatfish fishing grounds impacted by the wind farm scenario previously provided about $50 \%$ of flatfish catches in the German North Sea. This shows the importance of accounting for preference areas in fishing in the development of spatial management options. For this scenario our set of fishing effort reallocation rules aimed to represent a linear decrease in fishing effort with increasing distance from areas closed to fishing (see Stelzenmüller et al. 2008 and references therein). Yet fishermen's responses to areas closed to fishing are often more complex and call for case-specific models, like the bio-economic model for Mediterranean swordfish by Tserpes et al. (2009) or individual-based models which incorporate factors such as fuel prices or market development (BEMMFISH 2005). The aggregation of fishing vessels in smaller areas outside closed areas could also lead to increased competition and conflict (Shipp 2003). Moreover, the social consequences of fishing effort allocations due to spatial management measures could also comprise a general interest of fishermen to increase fishing capacity due to increased steaming time, which stands in contrast to current fisheries management practice (Agardy 2010, Agardy et al. 2011 and references therein). For the North Sea only a few studies analyse the resource distribution, spatial management, effort allocation and economic aspects of fisheries separately or in pairs (Marchal et al. 2002, 2007, Poos et al. 2009). As yet, studies integrating all aspects are still lacking. This highlights the fact that the prediction of fishermen's responses to management often represents a knowledge gap that hinders the construction of more realistic scenarios which are crucial for sound decision-making in ecosystem-based management.

Once improved knowledge on fishing patterns and fishermen's responses becomes available, such information could be incorporated into our modelling framework; this would enable the integration of other relevant factors and their relationships or other model outcomes representing, for instance, the spatial distribution patterns of fishing activities. Future applications could also address the potential cross-border consequences (economic and ecological) of spatial management scenarios in the German EEZ of the North Sea.

Both scenario outcomes reflect spatial management options under assumed management objectives rather than final solutions. Like any modelling technique our BN-GIS framework, constructed to describe complex relationships between human activities and sensitive ecosystem components, is constrained by the available data at the relevant spatial scale. Thus, interpretations of the results are specific to the spatial scale of the study area (see Marcot et al. 2006). Further, BN models require the full probability structure of the variables and their relationships, which is not a straightforward task in cases with poor data or which require expert judgement. Also, there are limitations regarding the level of complexity that can be consistently assessed by BN models (Marcot et al. 2006).

Any decision-making process in environmental management requires both the assessment of probabilities of certain outcomes (risk analysis) and the consideration of a manager's attitude to risk (risk management) in order to validate the level of uncertainty about whether or not a management decision 
Baseline scenario Vulnerability State 2

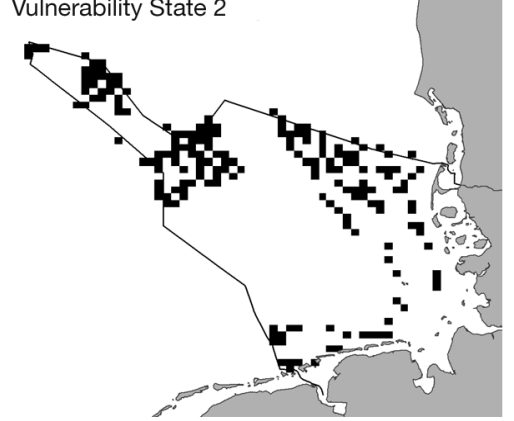

Vulnerability State 4

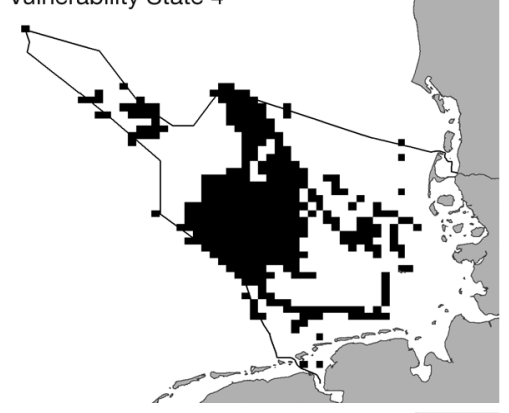

Vulnerability State 5

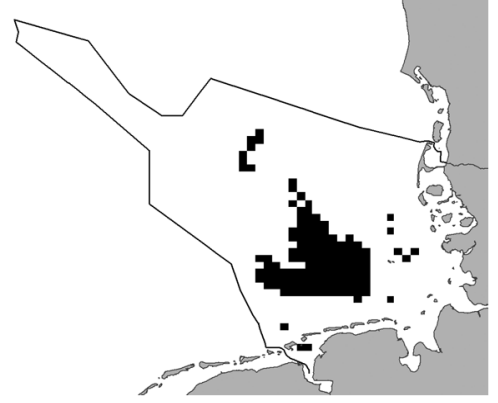

Estimated distribution vulnerability

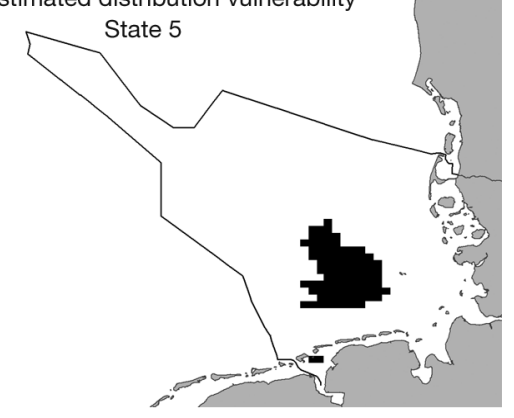

Fig. 7. Example results for Scenario 2 on the assessment of changes in spatial patterns of vulnerability states (black squares) after the closure of wind farm application areas to fishing, together with a displacement of fishing effort. Distribution of cells in the vulnerability States 2, 4 and 5 according to the baseline scenario (left panels) and the distribution patterns of the predicted

States 2, 4 and 5 in Scenario 2 (right panels) are displayed
Scenario 2

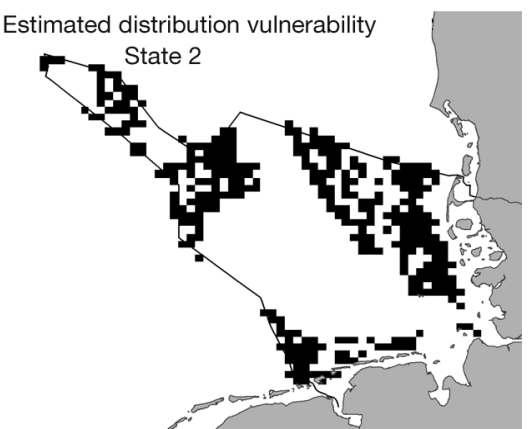

Estimated distribution vulnerability State 4
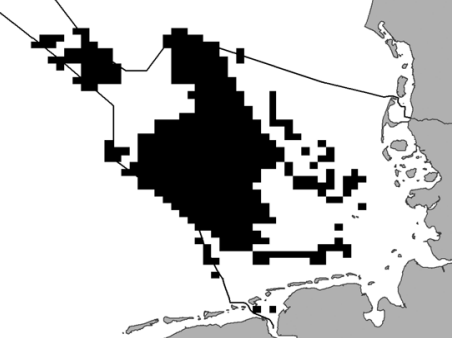

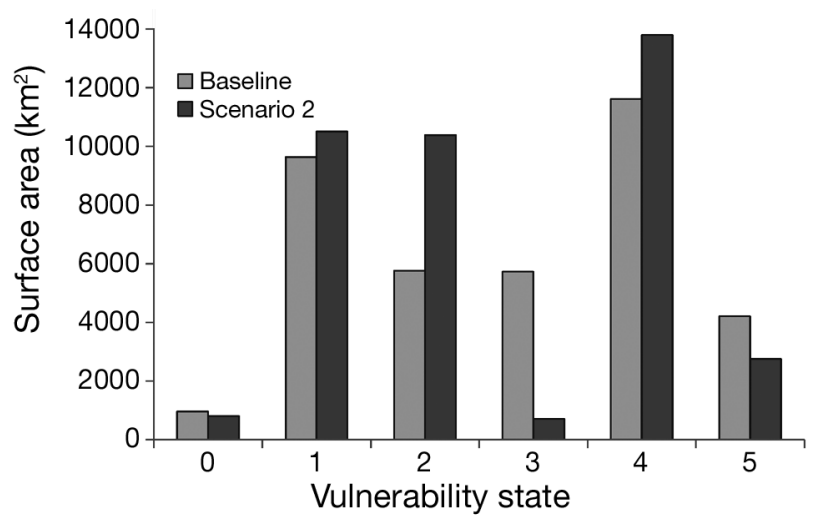

Fig. 8. Relative comparison of surface area $\left(\mathrm{km}^{2}\right)$ and vulnerability state between the baseline scenario and Scenario 2 will lead to the desired outcome (see Marcot et al. 2006 and references therein). BNs can incorporate nodes representing potential management decisions or the utility of outcomes and allow for a comparison of outcome values weighted by their relative probabilities. Ultimately, to be of direct use for decision-making in marine spatial management, BN models and related scenarios require clear management objectives. Marine spatial planning aims to achieve multiple objectives by managing human activities in space and time; thus, assessing the risk of failing to complete those objectives is an essential component of adaptive management (Douvere \& Ehler 2009, 2010).

In summary, our results showed the potential range of applications of the spatially explicit and integrated modelling framework. One of the main advantages of this approach is the ability to spatially examine the spatial pattern of uncertainty related to spatial management options, which is crucial for MSP. Further, to support the actual decision-making process in spatial management, the modelling framework presented needs to be adapted to each case according to the available data, spatial scale and management objectives. For instance, once the driving factors of fishermen's behaviour are known, more realistic scenarios can be defined to assess spatial management options in our study area. Ideally, management objectives also include a definition of targets and thresholds against which predicted changes can be assessed. In other words, to adopt our proposed vulnerability measure in a risk-management framework, thresholds would be required reflecting the maximum level of acceptable vulnerability of plaice to fishing. We conclude that the approach presented would be a useful tool in facilitating informed decisions through the spatially explicit assessment of potential risks and in relinquishing the related uncertainty concerning spatial management options.

Acknowledgements. The effort data used in the present study for Denmark and the Netherlands were collated during the plaice evaluation project (PBOX funded by DG Mare) and were kindly provided by Josefine Egekvist (DTU Aqua) and Doug Beare (IMARES). 


\section{LITERATURE CITED}

Agardy T (2010) Ocean zoning: making marine management more effective. Earthscan, Oxford

> Agardy T, di Sciara GN, Christie P (2011) Mind the gap: addressing the shortcomings of marine protected areas through large scale marine spatial planning. Mar Policy 35:226-232

Akaike H (1973) Information theory and an extension of the maximum likelihood principle. In: Petrov BN, Csaki F (eds) Proceedings of the 2nd International Symposium on Information Theory. Akadémiai Kiadó, Budapest, p 267-281

> Ban NC, Alidina HM, Ardron JA (2010) Cumulative impact mapping: advances, relevance and limitations to marine management and conservation, using Canada's Pacific waters as a case study. Mar Policy 34:876-886

BEMMFISH (2005) Final report. Bio-economic modelling of Mediterranean fisheries. EU Research Program. CSIC, Barcelona. www.mefisto.info/bibliogr/Final_Report_ BEMMFISH.pdf

Berkenhagen J, Döring R, Fock HO, Kloppmann MHF, Pedersen SA, Schulze T (2010) Decision bias in marine spatial planning of offshore wind farms: problems of singular versus cumulative assessments of economic impacts on fisheries. Mar Policy 34:733-736

BMVBS (2009) Spatial plan for the German Exclusive Economic Zone in the North Sea. Available at: www. bshde/en/Marine_uses/Spatial_Planning_in_the_German_ EEZ/indexjsp (accessed on 2 May, 2011)

Christensen V, Ferdaña Z, Steenbeek J (2009) Spatial optimization of protected area placement incorporating ecological, social and economical criteria. Ecol Model 220: 2583-2593

COM (2008) Roadmap for maritime spatial planning: achieving common principles in the EU. European Commission, Brussels

Commission E (2008) Directive 2008/56/EC of the European Parliament and of the Council of 17 June 2008, establishing a framework for community action in the field of marine environmental policy (Marine Strategy Framework Directive). Off J Eur Union L164:19-40

Cressie NAC (1991) Statistics for spatial data. John Wiley \& Sons, New York, NY

> De Lange HJ, Sala S, Vighi M, Faber JH (2010) Ecological vulnerability in risk assessment - a review and perspectives. Sci Total Environ 408:3871-3879

> Douvere F, Ehler CN (2009) New perspectives on sea use management: initial findings from European experience with marine spatial planning. J Environ Manag 90:77-88

Douvere F, Ehler CN (2010) The importance of monitoring and evaluation in adaptive maritime spatial planning. J Coast Conserv 5:305-311

Ehler C, Douvere F (2009) Marine spatial planning: a stepby-step approach toward ecosystem-based management. Intergovernmental Oceanographic Commission and Man and the Biosphere Programme. I. In: IDNPU (eds) OC manual and guides, No. 53 IOCAM Dosier no. 6. UNESCO, Paris

Ellison AM (1996) An introduction to Bayesian inference for ecological research and environmental decision-making. Ecol Appl 6:1036-1046

Fock HO (2008) Fisheries in the context of marine spatial planning: defining principal areas for fisheries in the German EEZ. Mar Policy 32:728-739
Fock HO (2011a) Integrating multiple pressures at different spatial and temporal scales: a concept for relative ecological risk assessment in the European marine environment. Hum Ecol Risk Assess 17:187-211

Fock HO (2011b) Natura 2000 and the European Common Fisheries Policy. Mar Policy 35:181-188

Fock HO, Kloppmann M, Stelzenmüller V (2011) Linking marine fisheries to environmental objectives: a case study on seafloor integrity under European maritime policies. Environ Sci Policy 14:289-300

Foden J, Rogers SI, Jones AP (2010) Recovery of UK seabed habitats from benthic fishing and aggregate extractiontowards a cumulative impact assessment. Mar Ecol Prog Ser 411:259-270

- Foley MM, Halpern BS, Micheli F, Armsby MH and others (2010) Guiding ecological principles for marine spatial planning. Mar Policy 34:955-966

Halpern BS, Walbridge S, Selkoe KA, Kappel CV and others (2008) A global map of human impact on marine ecosystems. Science 319:948-952

Hastie T, Tibshirani R (1986) Generalized additive models. Stat Sci 1:297-318

> Hayes EH, Landis WG (2004) Regional ecological risk assessment of a near shore marine environment: Cherry Point, WA. Hum Ecol Risk Assess 10:299-325

Hengl T, Heuvelink GBM, Rossiter DG (2007) About regression-kriging: from equations to case studies. Comput Geosci 33:1301-1315

Kennedy MC, Ford ED, Singleton P, Finney M, Agee JK (2008) Informed multi-objective decision-making in environmental management using Pareto optimality. J Appl Ecol 45:181-192

> Lackey RT (1998) Seven pillars of ecosystem management. Landsc Urban Plan 40:21-30

> Landis WG (2004) Ecological risk assessment conceptual model formulation for nonindigenous species. Risk Anal 24:847-858

Leslie HM, McLeod KL (2007) Confronting the challenges of implementing marine ecosystem-based management. Front Ecol Environ 5:540-548

> Marchal P, Ulrich C, Pastoors M (2002) Area-based management and fishing efficiency. Aquat Living Resour 15: 73-85

Marchal P, Poos JJ, Quirijns F (2007) Linkage between fishers' foraging, market and fish stocks density: examples from some North Sea fisheries. Fish Res 83:33-43

- Marcot BG, Holthausen RS, Raphael MG, Rowland MM, Wisdom MJ (2001) Using Bayesian belief networks to evaluate fish and wildlife population viability under land management alternatives from an environmental impact statement. For Ecol Manag 153:29-42

Marcot BG, Steventon JD, Sutherland GD, McCann RK (2006) Guidelines for developing and updating Bayesian belief networks applied to ecological modeling and conservation. Can J For Res 36:3063-3074

Martin CS, Carpentier A, Vaz S, Coppin F and others (2009) The channel habitat atlas for marine resource management (CHARM): an aid for planning and decisionmaking in an area under strong anthropogenic pressure. Aquat Living Resour 22:499-508

Maxwell DL, Stelzenmüller V, Eastwood PD, Rogers SI (2009) Modelling the spatial distribution of plaice (Pleuronectes platessa), sole (Solea solea) and thornback ray (Raja clavata) in UK waters for marine management and planning. Neth J Sea Res 61:258-267 
McCann RK, Marcot BG, Ellis R (2006) Bayesian belief networks: applications in ecology and natural resource management. Can J For Res 36:3053-3062

Munk P, Fox CJ, Bolle LJ, Van Damme CJG, Fossum P, Kraus G (2009) Spawning of North Sea fishes linked to hydrographic features. Fish Oceanogr 18:458-469

Murawski SA, Wigley SE, Fogarty MJ, Rago PJ, Mountain DG (2005) Effort distribution and catch patterns adjacent to temperate MPAs. ICES J Mar Sci 62:1150-1167

Nyberg JB, Marcot BG, Sulyma R (2006) Using Bayesian belief networks in adaptive management. Can J For Res 36:3104-3116

> Olsen E, Ring Kleiven A, Skjoldal HR, von Quillfeldt CH (2011) Place-based management at different spatial scales. J Coast Conserv 15:257-269

Pedersen SA, Fock H, Krause J, Pusch C and others (2010) Natura 2000 sites and fisheries in German offshore waters. ICES J Mar Sci 66:155-169

Polasky S, Nelson E, Camm J, Csuti B and others (2008) Where to put things? Spatial land management to sustain biodiversity and economic returns. Biol Conserv 141: 1505-1524

Poos JJ, Bogaards JA, Quirijns FJ, Gillis DM, Rijnsdorp AD (2009) Individual quotas, fishing effort allocation, and over-quota discarding in mixed fisheries. ICES J Mar Sci 67:323-333

Quinn TJ II, Deriso RB (1999) Quantitative fish dynamics. Oxford University Press, New York, NY

Rijnsdorp AD, Daan N, Dekker W (2006) Partial fishing mortality per fishing trip: a useful indicator of effective fishing effort in mixed demersal fisheries. ICES J Mar Sci 63: 556-566

Ruckelshaus M, Klinger T, Knowlton N, DeMaster DP (2008) Marine ecosystem-based management in practice: scientific and governance challenges. Bioscience 58:53-63

Shipp RL (2003) A perspective on marine reserves as a fishery management tool. Fisheries (Bethesda) 28:10-21

Smith RJ, Eastwood PD, Ota Y, Rogers SI (2008) Developing best practice for using Marxan to locate marine protected

Editorial responsibility: Jake Rice,

Ottawa, Canada areas in European waters. ICES J Mar Sci 66:188-194

Spiegelhalter DJ, Dawid P (1993) Bayesian analysis in expert systems. Stat Sci 8:219-283

Stelzenmüller V, Maynou F, Martín P (2007) Spatial assessment of benefits of a coastal Mediterranean Marine Protected Area. Biol Conserv 136:571-583

Stelzenmüller V, Maynou F, Bernard G, Cadiou G and others (2008) Spatial assessment of fishing effort around European marine reserves: implications for successful fisheries management. Mar Pollut Bull 56:2018-2026

Stelzenmüller V, Lee J, Garnacho E, Rogers SI (2010a) Assessment of a Bayesian Belief Network-GIS framework as a practical tool to support marine planning. Mar Pollut Bull 60:1743-1754

> Stelzenmüller V, Lee J, South A, Rogers SI (2010b) Quantifying cumulative impacts of human pressures on the marine environment: a geospatial modelling framework. Mar Ecol Prog Ser 398:19-32

Tallis H, Levin PS, Ruckelshaus M, Lester SE, McLeod KL, Fluharty DL, Halpern BS (2010) The many faces of ecosystem-based management: making the process work today in real places. Mar Policy 34:340-348

Teal LR, De Leeuw JJ, Van Der Veer HW, Rijnsdorp AD (2008) Effects of climate change on growth of 0-group sole and plaice. Mar Ecol Prog Ser 358:219-230

Tserpes G, Tzanatos E, Peristeraki P, Placenti V, Kell L (2009) A bio-economic evaluation of different management measures for the Mediterranean swordfish. Fish Res 96:160-166

> Varis O, Kettunen J, Sirvio H (1990) Bayesian influence diagrams in complex environmental management including observational design. Comput Stat Data Anal 9:77-91

> Venables WN, Dichmont CM (2004) A generalised linear model for catch allocation: an example from Australia's northern prawn fishery. Fish Res 70:409-426

Watts ME, Ball IR, Stewart RS, Klein CJ and others (2009) Marxan with zones: software for optimal conservation based land- and sea-use zoning. Environ Model Softw 24:1513-1521

Submitted: May 19, 2011; Accepted: August 19, 2011 Proofs received from author(s): November 10, 2011 